\title{
Assessment of the effects rejections of feed fish on water resources. (Ouedoumerrbia, Morocco)
} \author{
Khadija Ouaissa $^{1,2}$, AssiaKritihi $^{1,2}$, YounessOumessoud
MustaphaHasnaoui \\ ${ }^{(1}$.Environnemental engineering Teams. Department of Biology, Facylty of Sciences and Techniques \\ Beni-Mellal. University Sultan Moulay Slimane. M' Ghila, B.O 523. 23000 Beni-Mellal, Morocco \\ (2. Fish Farming AinAghbal, Azrou-Morocco.
}

\begin{abstract}
Summary. In order to compare the effects of three types of extruded food (A,B and $\mathrm{C})$ on the growth of rainbow trout, an experimental test was conducted on June 15, 2015 at a rainbow trout farming station near river of Oumerrrabi .Morocco.

The comparison of three foods of different composition and energy is performed in isoenergetic conditions.

Six basins were used for this comparative test. These basins are fed with fresh water according to the open circuit with a renewal of twice an hour. The initial feeding conditions were the same for the three food types and the initial density of $1,58 \mathrm{~kg} / \mathrm{m}^{3}$ ( $\mathrm{kg}$ by volume) and an initial flow rate of $1,04 \mathrm{~m}^{3} / \mathrm{h}$.

Fish are fed by ratios two to three times a day depending on the magnification stage.

The sampling frequency is fortnightly, where we measure the zootechnical performance of fish and collect water samples for physicochemical analyses in order to assess the quality of the water leaving in the basins before their discharge into the river of Oum Er-Rbia.

The comparative trial of three fish foods $(\mathrm{A}, \mathrm{B}$, and $\mathrm{C})$ revealed that diet $\mathrm{B}$ is the better formulation reflected by the zootechnical performances and low phosphate release than $\operatorname{diet} \mathrm{A}$ and $\mathrm{C}$.
\end{abstract}

Keywords: Food; biochemical; Performance; Releases; Environment; OumErRbia; Morocco. 


\section{Introduction}

The aquaculture products are becoming increasingly important in human nutrition. In the context of sustainable control of the salmonids production, it is essential to optimize feed and maintain a high quality finished product to meet customer requirements and environmental requirements.

Aquaculture is a sector of food production that has changed in recent years. Farmed fish is currently nearly $50 \%$ of the fish world [1] . This explosive growth has led the aquaculture industry to significant challenges. The most important of them is the reduction of the negative impacts of aquaculture on the environment practices. These effects are still many. However, eutrophication of streams effluent receiving aquaculture companies is the aspect most concern [2]. These environmental concerns have led researchers and producers to explore possible solutions to move aquaculture more sustainable development.

Proteins in the diet of farmed fish are mainly brought by fishmeal as an essential element in the artificial diet. With a view to preserving the environment and the non-dependence of sources of raw materials such as fishmeal. Food for trout is becoming increasingly rich in fish meal because its extra energy intake. Fishmeal is the main ingredient in the food composition of rainbow trout, it covers a large percentage in the formulation of carnivore food fish, and this ingredient is rich in phosphate that which participates in the skeletal formation of fish.

The negative environmental impacts of aquaculture are very numerous, but the most danger is the eutrophication of effluents on aquaculture farms [3], [4], [5] and [6]. The main pollutants involved in this phenomenon are phosphorus $(\mathrm{P})$.

In the context of a sustainable control of trout farming, the reserve of water resources and protection of the environment. The objective of this study is to compare three types of food extruded different biochemical compositions on the zootechnical performance of rainbow trout to determine foods that have the best trout growth performance, digestibility in order to limit and optimize fish in emissions more than engage in sustainable aquaculture that respects the environment and that respect environmental standards.

For economic and ecological reasons, the comparative test of three food (A, B and C) realized in the station of Oum Er-Rbiaa magnification allowed to retain the $\mathrm{B}$ diet presented a better performance zootechnique and low phosphorus rejection [7].

\section{Materials and methods}

\subsection{Experimental study}

The experiment was conducted on June 15, 2015 at the fish farm of Oumerrabia, located about $70 \mathrm{~km}$ from Azrou (Morocco).

The six basins are fed by spring water at $14^{\circ} \mathrm{C}$. The water, that supplements the tanks, was renewed every half hour (48 times /days) with high level of oxygen (more than $90 \%$ saturation).

4574 Trout, of average weight of $40 \mathrm{~g}$, were sampled from the same batch of eggs and divided randomly into six tanks. The test was conducted in monoculture and the fish were fed manually with a determined daily ration.

Every 15 days, 90 fish (according to Student's law) are captured from each tank, being fasted for 24 hours and then anesthetized to measure the size and the weight of each fish, weight gain (WG), feed conversion ratio (FCR), Specific growth ratio (SGR), and factor condition $(\mathrm{K})$. 
The distributed foods were weighted to estimate the consumption by the fish between two successive Sampling

\subsection{Experimental food}

\subsubsection{Composition of the three foods tested}

The biochemical analyses (proteins, lipids, moisture and ash) of the extruded foods used in this experiment were performed in duplicate using the standard [8] and concerned:

-Moisture doses the desiccation method at $105^{\circ} \mathrm{c}$.

-Crude proteins $(\% \mathrm{~N} * 6.25)$ are determined by the Kjeldahl method (self-analyser Kjel-FOSS)-

-Lipids by the hot method (type Soxhlet).

The extraction of lipids was carried out by a mixture of chloroform: methanol $(2: 1 \mathrm{~V} / \mathrm{V})$ According to the method of [9].

-Ash after incineration of the samples in the muffle oven à $550^{\circ} \mathrm{c}$ for 12 hours,

-The carbohydrate content, assimilated to the nitrogen Extractifnon (ENA), by a calculation of difference from the values found for the other constituents of the sample.

-Total phosphorus per continuous flow analysis.

-Raw energy measured by a calorimetry bomb. Apparatus measures the energy (in Joules) released in the form of heat by the total combustion of the sample.

The following table bellow shows the proximal composition of the extruded food

Table 1. Biochemical composition of the three foods tested according to supplier datasheets (different food diameters)

\begin{tabular}{|l|c|c|c|c|c|c|c|c|c|}
\hline Type of Foods & \multicolumn{3}{|c|}{ A } & \multicolumn{3}{c|}{ B } & \multicolumn{3}{c|}{ C } \\
\hline Food diameter & $3 \mathrm{~mm}$ & $4,5 \mathrm{~mm}$ & $7 \mathrm{~mm}$ & $3 \mathrm{~mm}$ & $4,5 \mathrm{~mm}$ & $7 \mathrm{~mm}$ & $3 \mathrm{~mm}$ & $4,5 \mathrm{~mm}$ & $7 \mathrm{~mm}$ \\
\hline Protein (\%) & 40 & 39 & 39 & 45 & 43 & 41 & 46 & 45 & 40 \\
\hline Lipid (\%) & 23 & 27 & 27 & 20 & 22 & 24 & 20 & 24 & 26 \\
\hline NFE (\%) & 21 & 18,2 & 18,2 & 20 & 20,7 & 20,5 & 15 & 14 & 13 \\
\hline Cellulose (\%) & 2,25 & 1,86 & 1,8 & 1,9 & 1,9 & 2,3 & 1 & 1 & 1 \\
\hline Ash (\%) & 7,20 & 6,77 & 6 & 8,1 & 7,4 & 7,2 & 10 & 10 & 10 \\
\hline $\begin{array}{l}\text { Phosphorus } \\
\text { (\%) }\end{array}$ & 1,05 & 0,98 & 0,9 & 1 & 1 & 1 & 1,5 & 1,5 & 1,40 \\
\hline DE (Mj/kg) & 19,2 & 20,2 & 20,2 & 20 & 20,3 & 20,6 & 19 & 19,90 & 20,50 \\
\hline $\begin{array}{l}\text { DP/DE (g /MJ) } \\
\text { Vitamin A }\end{array}$ & 19 & 17,5 & 17,5 & - & - & - & 22,30 & 22,30 & 17,60 \\
(UI.kg) & 17000 & 10000 & 10000 & 10000 & 10000 & 10000 & 10000 & 10000 & 10000 \\
\hline $\begin{array}{l}\text { Vitamin D3 } \\
\text { (UI.kg) }\end{array}$ & 1750 & 1750 & 1000 & 1000 & 1000 & 1850 & 1850 & 1850 \\
\hline $\begin{array}{l}\text { Vitamin E } \\
\text { (UI.kg) }\end{array}$ & 200 & 200 & 200 & 200 & 200 & 200 & 200 & 200 & 200 \\
\hline $\begin{array}{l}\text { Vitamin C } \\
\text { (UI.kg) }\end{array}$ & 150 & 150 & 150 & - & - & - & 180 & 180 & 180 \\
\hline
\end{tabular}




\subsection{Analyses of fish effluents}

To estimate the outflows of phosphorus $\left(\mathrm{HPO}_{4}{ }^{3-}\right)$ in outlet of the basins, water samples are taken twice per month consecutively.

The samples are then transported, in a cooler at $4{ }^{\circ} \mathrm{C}$, to the analysis laboratory of the OumEr-Rbia hydraulic basin agency in Beni-Mellal.

The water samples are then transported in a cooler at $4{ }^{\circ} \mathrm{c}$ to the laboratory of analysis of the hydraulic basin agency of Oumerrabia (ABHOER) of Beni-Mellal. Orthophosphate was measured by spectrophotometry after mineralization followed by acid hydrolysis (NFT 90013) [10].

\section{Results}

The following table presents the results of the zootechnical performance of the three foods $(\mathrm{A}, \mathrm{B}$ and $\mathrm{C})$ in the three stages of rearing fed by the different food diameters $(3 \mathrm{~mm}$, $4,5 \mathrm{~mm}$ and $7 \mathrm{~mm}$ ) obtained during this test Experimental.

Table 2. The zootechnical parameters studied for the three foods tested (A, B and C).

\begin{tabular}{|c|c|c|c|c|c|c|c|c|c|}
\hline \multirow[t]{2}{*}{ Settings } & \multicolumn{3}{|c|}{$\mathbf{A}$} & \multicolumn{3}{|c|}{$\mathbf{B}$} & \multicolumn{3}{|c|}{$\mathbf{C}$} \\
\hline & $3 \mathrm{~mm}$ & $4,5 \mathrm{~mm}$ & $7 \mathrm{~mm}$ & $3 \mathrm{~mm}$ & $4,5 \mathrm{~mm}$ & $7 \mathrm{~mm}$ & $3 \mathrm{~mm}$ & $4,5 \mathrm{~mm}$ & $7 \mathrm{~mm}$ \\
\hline Initial weight (g) & 41,05 & 143,28 & 495 & 41,15 & 147,22 & 501,1 & 44,65 & 132,68 & 481,9 \\
\hline Final Weight (g) & 143,28 & 495 & 803,14 & 147,22 & 501,1 & 1043,9 & 132,68 & 481,9 & 942,1 \\
\hline Number of days & 60 & 90 & 72 & 75 & 75 & 72 & 60 & 90 & 72 \\
\hline weight Gain (g) & 101,33 & 351,72 & 308,14 & 106,07 & 353,88 & 542,8 & 88,03 & 449,22 & 460,2 \\
\hline $\begin{array}{l}\text { Specific growth } \\
\text { rate\% (SGR) }\end{array}$ & 2,08 & 2,76 & 0,66 & 1,7 & 1,62 & 1,02 & $\mathbf{1 , 8 1}$ & 1,43 & $\mathbf{0 , 9 3}$ \\
\hline $\begin{array}{l}\text { Individual daily } \\
\text { Growth (IDG) }\end{array}$ & 1,7 & 3,9 & 4,27 & 1,41 & 4,71 & 7,53 & 1,46 & 3,88 & 6,39 \\
\hline Survival rate (\%) & 98 & 99,59 & 99,82 & 95,5 & 99,82 & 99,82 & 99,4 & 99,76 & 99,82 \\
\hline Conversion Index & 0,8 & 1 & 1,1 & $\mathbf{0 , 8}$ & 0,9 & 0,9 & $\mathbf{0 , 9}$ & $\mathbf{0 , 8}$ & $\mathbf{0 , 8}$ \\
\hline Condition factor & 1,2 & 1,22 & 1,27 & 1,27 & 1,45 & 1,61 & 1,08 & 1,28 & $\mathbf{1 , 0 3}$ \\
\hline
\end{tabular}

During the experimental period, the test was carried out under the same conditions for the three tested foods A, B and C.

Table 2 shows the growth performance of rainbow trout during the experimentation period, food B is still the most efficient (weight gain, specific growth rate and daily individual growth, Conversion index and condition factor ) which gives results of greater growth and better performance compared to the other two foods tested. 


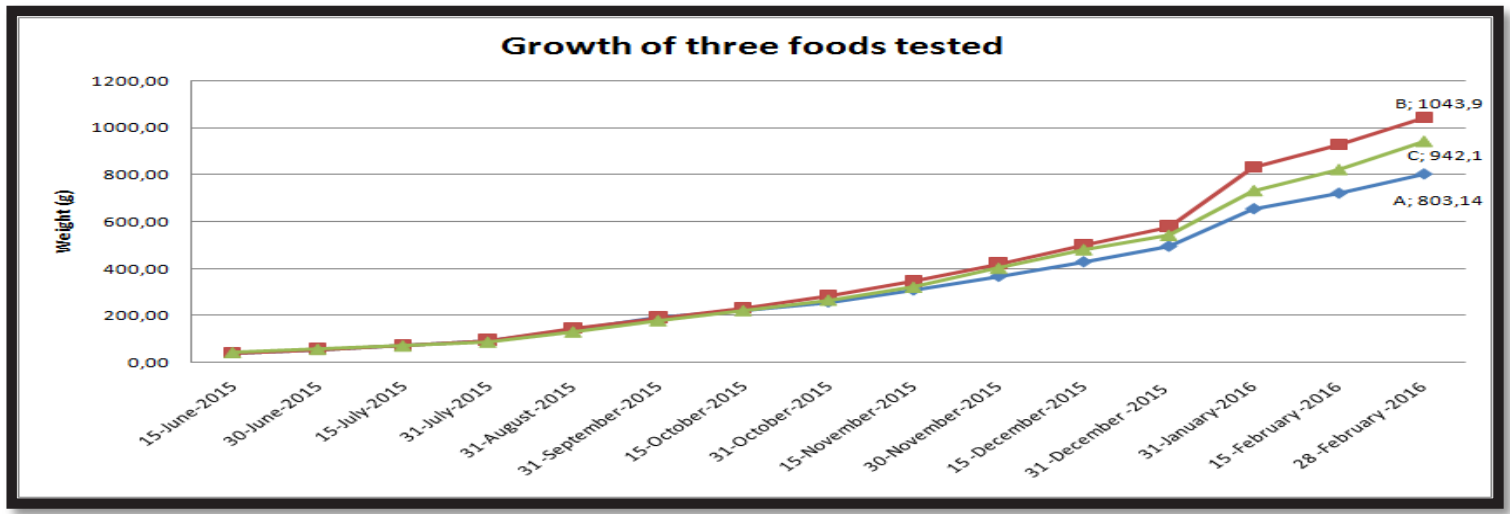

Fig. 1.Growth of three types foods (A, B and C)

During the experimental period, the test was carried out under the same conditions of breeding for the three tested foods A, B and C (temperature, source and flow of water).

Table 2 shows the growth performance of rainbow trout during the experimental period. $\mathrm{B}$ food is still the most efficient (weight gain, specific growth rate and daily individual growth). Greater growth and better performance compared to the other two foods tested (A and $\mathrm{C}$ ).

Weight growth has a major impact on production. It reflects the effectiveness of the food in mass production. For this reason, a regular trout weight measurement was carried out throughout the experimental test.

The graphical representation of the evolution of the average weight of rainbow trout fed by three types of iso-energy food but of different biochemical composition is shown in table 1 .

This indicates that B diet is the best food at the end of growth with a growth of $1043.9 \mathrm{~g}$ compared to foods A and C (803.14g) and (942.1g) despite a lower lipid content to the other two foods $\mathrm{A}$ and $\mathrm{C}$.

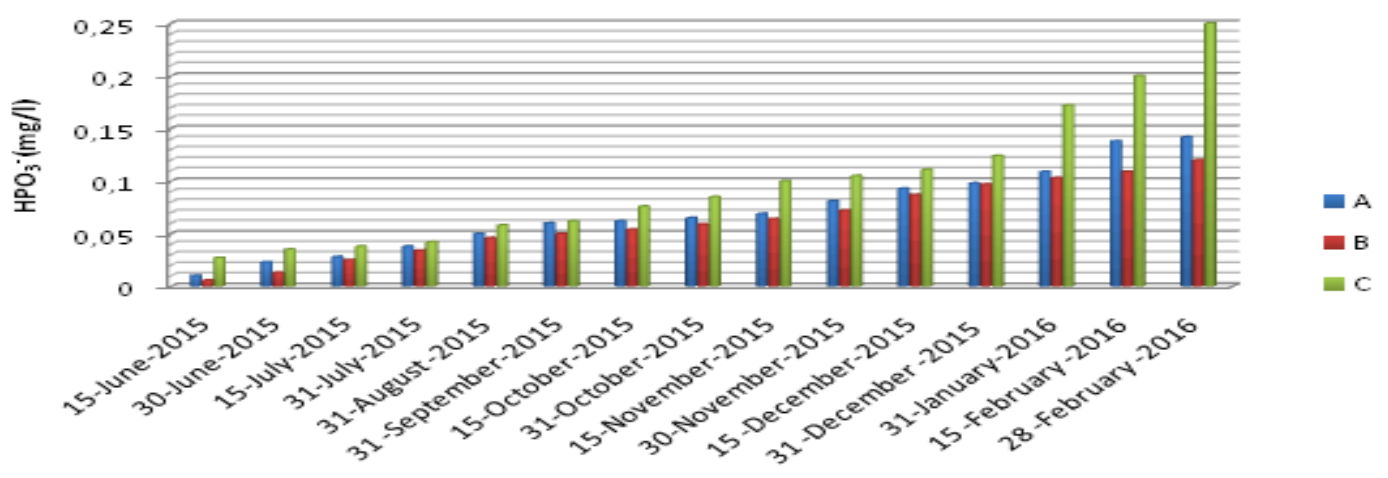

Fig. 2 . Rate of phosphorus discharges

(Fig.2) present the results of phosphate analyses of water from fish effluents in the basins of the three extruded foods tested.

For the phosphorus rejection of trout, the results show that $\mathrm{C}$ fed fish release more phosphate releases than food $\mathrm{A}$ and $\mathrm{B}$, the amount of releases increases as a function of fish biomass and the food distributed.

Food B releases are always lower than the two foods A and C. 


\section{Discussion}

The trout were kept under optimal conditions throughout the trial period, as the values obtained for temperature, dissolved oxygen and $\mathrm{pH}$ met the standards for breeding these fish [11], [12].

In high trophic level fish it is the proteins and dietary lipids that allow them to cover their energy needs because of limited capacities used efficacement the energy of food carbohydrates [13].

According to this comparative study of three foods, the results show that feed B ensures a significant growth of trout compared to food A and C in effect of 1043.9gr, compared to 883.1gr for food A and 942.1 gr for food C.

The extruded food B provided better zootechnical performance during the three breeding stages (40-100g; 100-500g; 500-1000 g) compared with food A and C.

It was found that growth also was increased by the increase in lipid levels in diet $\mathrm{C}$, the final weight of fish fed by food $\mathrm{B}$ is greater than $\mathrm{C}$ food knowing that they have almost the same protein content $(\mathrm{B}=39 \%$ and $\mathrm{C}=40 \%$ ) in the biochemical composition but with a different lipid level, these results obtained are similar to the results obtained by [14].

Many studies have showed that a high-energy diet acts on the growth and food efficiency of fish food proteins [15]. However, supplementation with fat rather than carbohydrates, as a non-protein source of energy, is generally more effective because lipids are easily metabolized, especially by fish carnivores like rainbow trout [16].

Our results confirm the existence of a load efficiency, where a better growth recorded for food $\mathrm{b}$ which translates to $1043.9 \mathrm{~g}$, compared to food $\mathrm{C}$ (760 g) and food A (726.4 g), knowing that food $\mathrm{B}$ has a low content fat in the stage of magnification which has a content of (24\%) against food A and $\mathrm{C}$ which have high lipid content $(27 \%)$ and $(26 \%)$ This is contradictory to the results found in [16].

The food conversion index is the ratio of food consumed on weight gain. It must be as low as possible, reflecting a good efficacy of the food in question and its proper use by the animal.

The conversion index recorded in this study represented by $\left(\mathrm{CI}_{\mathrm{B}}=0.9\right)$ are comparable to those obtained by [17] and those reported by [18]whose experimental studies relate to the effect of two extruded foods on the performance of rainbow trout and are indicative of good growth and food conversion efficiency of 0.88 .

Survival rates are clear that we have not recorded major problems in terms of mortality; the survival rate exceeds $95 \%$ for the three diets (A, B and C) and in the three breeding stages (40-100g. $100 \mathrm{~g}-500 \mathrm{~g}$ and $500-1 \mathrm{~kg}$ ).

The few dead individuals counted during the experiment did not appear to be related to diet but to external factors. Therefore, we consider that our results are in the accepted standard.

We found that the $\mathrm{K}$-factor is very important in diet $\mathrm{B}$ of $\left\{\mathrm{K}_{\mathrm{B}}=1.61\right\}$, which has an excellent state of health, which explains that the fish undergoing this diet grew better at the levels of the weight and length ratio; While for an extruded $\mathrm{C}$ diet, we reflect that the fish had a larger performance size than the weight performance and this can only be explained by the richness of $\mathrm{C}$ food by phosphorus.

We found that the $\mathrm{K}$ factor is very important in the $\mathrm{B}$ regimen of $\{\mathrm{KB}=1.61\}$, which has an excellent health condition, which explains that the fish that are in this diet increased better at the weight and length ratios; While for an extruded $\mathrm{C}$ diet, we reflect that fish had a larger performance size than weight performance and this can only be explained by the richness of $\mathrm{C}$ food by phosphorus hence an important development of skeleton of fish bones 
All the phosphorus needed for fish comes from their diet. The phosphorus produced will therefore be a function of the quantity present in the food. Phosphorus can be of animal origin (bone meal, fish meal), vegetable or mineral. The digestibility of phosphorus is very variable depending on the species and the origin of phosphorus. The phosphorus of a good quality fish meal is $60 \%$ digestible by rainbow trout [19]. On the other hand, phosphorus of plant origin is in the form of calcium and magnesium salts of phytic acid. This phosphorus is very little used by fish because they do not have the phytase enzyme necessary to digest them [20].

Excess phosphorus in fish feeds results in higher levels of excreted phosphate, which is the main cause of eutrophication in aquatic environments and consequently the deterioration of water quality [21]

The reduction of phosphate excretion by fish has become imperative [22] in general, fish with the stomach, such as trout, assimilate more phosphorus than fish without the stomach, such as carp [23].

The $(\mathrm{P})$ requirement available for growth is 0.37 and $0.57 \%$ for better mineral accretion. While the food C comprises $1.5 \%$ in the food used and on the other hand it rejects more phosphorus and contributed to growth in size rather than weight.

The results obtained in this study are consistent with those obtained by [24] on rainbow trout (OnchorynkissMykiss), whose test revealed a high concentration of phosphorus releases by food, which is the same food used in our comparative test.

The phosphorus found in fish effluents are presenting in soluble or dissolved form. Phosphate releases are below the environmental standard at a rate of $0.12 \mathrm{mg} / 1$ for a weight of $1 \mathrm{~kg}$ of fish, this may explain the efficiency of the production process of the feed extruded by excellent gelatinization of raw material vegetable and also by the choice of raw materials that has low phosphate levels. On the other the food tested a rate of $1 \%$ phosphate incorporated into the food, some countries developed in the field of food manufacturing have adopted measures limiting phosphorus levels in fish feed by $(<1 \%)$.(Kaushik,2000)

\section{Conclusion}

The results of this study show that the extruded food B characterized by its energy content, buoyancy, high digestibility and non-protein energy level, extruded food B trout provides the best zootechnical performancein terms of growth, conversion index. And also by a reduction of phosphate releases by controlling the formulation of food.Considering the food as the main cost of production in intensive fish farming with the use of the diets a better conversion and the contribution to the Sustainable aquaculture.

\section{Acknowledgements}

We thank Administration, Managers and staff of the fish farm Trout of the Atlas in Azrou for the financing and the realization of this study. 


\section{References:}

1. FAO, Rapport de la FAO sur la pêche et l'aquaculture (2010).

2. G. Ouellet, Caractérisation des eaux usées de stations piscicoles québécoises, MAPAQ, Direction de l'innovation et des technologies, 35 (1998).

3. D L .Corell, The role of phosphorus in the eutrophication of receiving waters: a review. Journal of Environmental Quality, 27: 261-266 (1998).

4. G .Ouellet, Les rejets des stations piscicoles et leurs impacts environnementaux, Québec, MAP AQ,42 (1999).

5. G .Persson, Eutrophication resulting from salmonid fish culture in fresh and salt waters: Scandinavian experiences. In Nutritional Strategies and Aquaculture Waste. Proceedings of the First International Symposium on Nutritional Strategies in Management of Aquaculture. University ofGuelph, Ontario, p. 163-185 (1991).

6. G.V. Vandenberg, Encapsulation de la phytase microbienne: Influences sur la disponibilité de nutriments chez la truite arc-en-ciel. Thèse de doctorat, Université Laval, Québec, 277 (2001).

7. K. Ouaissa, A. Kritihi, Y. Oumessoud, A. Maychal et Hasnaoui M, "Effets d'un aliment extrudé sur les performances de croissance de la truite arc-en-ciel (Oncorhynchusmykisswalbaum, 1792) et sur la qualité de l'eau de l'oued Oum Er-Rbia (station Ain Aghbal, Azrou-Maroc). "J. Wat. Env. Sci. Vol. 1, (S.I. COP22), 132139.(2017).

8. AOAC (Association of Official Analytical Chemists), Official methods of analysis of the Association of Official Analytical Chemists, " 15th edition. AOAC, Arlington, Virgina, USA.(1990).

9. J. Folch, M. Lees et Sloane-stanleyg H. S, A simple method for the isolation and purification of total lipids from animal tissues, " J. Biol. Chem. 226, 497-509 (1957).

10. AFNOR, Recueil de normes françaises des eaux : méthodes d'essais. Paris (1983).

11. G. A. Wedemeyer ,Physiology of fish in intensive culture systems.chapmanhall,LONDON.UK (1996).

12. S. J .Kaushik, Effect of digestible energy on nitrogen and energy balance in rainbowtrout. Aquaculture, 50, 89-10 (1985)

13. F Medale et J C. Guillaume, Nutrition énergétique. In : Guillaume .J, Kaushik S, Bergot P, Métailler R, Eds. Nutrition des poisons et des crustacés. Paris (France): INRA, pp. 87-111. (1985).

14. P. Luquet, Etude du développement chez la truite. Evolution de la teneur en acides nucléiques dans diverses fractions corporelles. Ann. giol. anim. Bioch. Biophys., 11, 657668 (1971).

15. NRC, «Nutrient Requirements of Fish. National Academy Press, Washington, D.C., 114 p. 1993.

16. S. Chaiyapechara , M.T. Casten , R.W.Hardy and DONG F. M, Fish performance, fillet characteristics, and health assessment index of rainbowtrout (Oncorhynchusmykiss) fed diets containing adequate and high concentrations of ipid and vitamin E, " Aquaculture, 219: 715-738 (2003). 
17. J.E. Erika , A.H. David , P.F. Anthony, Effect of iso-energetic diets with different protein lipid content on the growth performance and heat increment of rainbow trout. Aquaculture 272 .723-736p (2007) .https://doi:10.1016/j.aquaculture.2007.09.006

18. C. Brauge ,M. Medale , G. Corraze . Effect of dietary carbohydrate levels on growth, body composition and glycaemia in rainbow trout, Oncorhynchus mykiss, reared in seawater. Aquaculture 123, 109-120. (1994) https://prodinra.inra.fr/record/115983

19. A. Dosdat, L'excrétion chez les poissons téléostéens, " La pisciculture française, n. 109, 18-29 (1992).

20. S.P. Lall ,Digestibility, metabolism and excretion of dietary phosphorus in fish. Dans : C.B. Cowey et C.Y. Cho (eds.). Nutritional Strategies and Aquaculture Waste. Proceedings of the First International Symposium on Nutritional Strategies in Management of Aquaculture Waste. University of Guelph, Guelph, Ontario, 21-36 (1991).

21. M. Rodehutscord, Z. Gregus, E. Pfeffer, Effect of phosphorus intake on faecal and non- faecal phosphorus excretion in rainbowtrout (Oncorhynchusmykiss) and the consequences for comparative phosphorus availability studies. Aquaculture, Amsterdam, 188:383-398. (2000).

22. J.P. Blancheton, Cahiers Agricultures. Volume 18, Numéro 2-3, 227-34 (2009).

23. A. Hernandez, S. Satoh, V. Kiron, T. Watanabe, Phosphorus retention efficiency in rain bowtroutfed diets with lowfish meal and alternative protein ingredients .FISHERIES SCIENCE 70 ,580-586. (2004).

24. M. Abba, D. Belghyti, M. Benabid . Effet de deux aliments pressés et extrudés sur les performances de croissance de la truite arc en ciel (Oncorhynchus mykiss) et leurs impacts sur environnementaux, ScienceLib,3,4706 (2011)

25. S. Kaushik, Feed formulation, diet development and feed technology CIHEAM" ,p.43-51, (2000) 